\title{
THE DEVELOPMENT OF A FLIGHT TERMINATION PARACHUTE SYSTEM FOR A 1900 LB PAYLOAD
}

\author{
Donald E. Wayet \\ Sandia National Laboratories§ \\ Albuquerque, New Mexico 87185
}

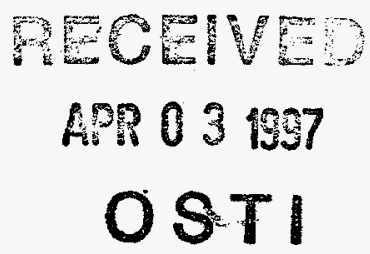

\begin{abstract}
A 30-ft-diameter ringslot/solid parachute was designed, developed, and tested at Sandia National Laboratories as the major component of a flight termination system required for a $1900-\mathrm{lb}$ gliding delivery platform. Four full-scale sled tests were performed to validate the design models of the parachute, determine reefing line length, demonstrate structural adequacy of the parachute materials, and demonstrate that performance met the design requirements.
\end{abstract}

\section{Introduction}

A 1900-lb. gliding delivery platform is being developed by Sandia National Laboratories with plans for a prototype test flight for conceptual demonstration. The test vehicle will be released from the delivery aircraft and use wing and fin surfaces to glide to an impact position. During testing of the new delivery platform at Tonopah Test Range there is a requirement for a system that will terminate the flight and protect valuable assets that are adjacent to the vehicle flight path in the unlikely event of system failure. In April of 1995, a parachute system was chosen as the primary method for flight termination. In addition, the parachute provided a secondary benefit of vehicle recovery which would offer an improved opportunity for failure analysis.

T Seniór Member of Technical Staff, Production Program Management Department, Associate Fellow of AIAA.

$\S$ Sandia is a multiprogram laboratory operated by Sandia Corporation, a Lockheed Martin Company, for the United States Department of Energy under contract DE-AC0494AL85000.

This paper is declared a work of the U.S. Government and is not subject to copyright protection in the United States.
The original vehicle proposed for the gliding delivery platform program weighed $1350 \mathrm{lbs}$. A two stage parachute system was designed for this 1350-lb payload. However, late in CY1995 the proposed design was modified and the weight increased to $1900 \mathrm{lbs}$.

A new parachute design philosophy was embraced with the increase in payload weight due to a requirement to maintain the same parachute volume and weight as that in the original design and an evolving understanding that the time for parachute deployment and inflation should be minimized. This new design required that the allowable deceleration loads on the vehicle be increased and also resulted in an increase in vehicle impact velocity.

The new parachute system design was completed in early 1996 using a new spreadsheet aided engineering design tool. Development and fabrication of the parachute components and packaging followed directly.

A sled test program was outlined to validate the parachute model and demonstrate parachute system performance and structural adequacy. Three tests were planned with parachute deployment conditions at maximum, minimum, and $120 \%$ maximum design dynamic pressure. Due to structural failure of the parachute on the first test at maximum dynamic pressure the parachute was redesigned and the first test was repeated before continuing with the two remaining tests in the program. The results of the four sled tests are presented.

\section{Parachute System Requirements and Constraints}

The primary requirement for the flight termination parachute system was to reliably terminate the flight of the vehicle within a DISTRIBUTAOY OF THS DOCUAEN IS UAMTIED 1

American Institute of Aeronautics and Astronautics 


\section{DISCLAIMER}

This report was prepared as an account of work sponsored by an agency of the United States Government. Neither the United States Government nor any agency thereof, nor any of their employees, make any warranty, express or implied, or assumes any legal liability or responsibility for the accuracy, completeness, or usefulness of any information, apparatus, product, or process disclosed, or represents that its use would not infringe privately owned rights. Reference herein to any specific commercial product, process, or service by trade name, trademark, manufacturer, or otherwise does not necessarily constitute or imply its endorsement, recommendation, or favoring by the United States Government or any agency thereof. The views and opinions of authors expressed herein do not necessarily state or reflect those of the United States Government or any agency thereof. 


\section{DISCLAMMER}

Portions of this document may be illegible in electronic image products. Images are produced from the best available original document. 
minimized flight path distance. For the original $1350 \mathrm{lb}$. vehicle the maximum deceleration load was established as $10 \mathrm{~g}$ 's $(13,500 \mathrm{lbs})$. When the vehicle weight was increased to $1900 \mathrm{lbs}$ an additional requirement for the parachute to minimize the flight path distance was added. We requested that the maximum deceleration load be increased to $15 \mathrm{~g}$ 's $(28,500 \mathrm{lbs}$.) so that this added requirement could be adequately satisfied.

The projected flight profile for the prototype test resulted in a maximum dynamic pressure parachute deployment condition of $872 \mathrm{lbs} / \mathrm{ft}^{3}$. This condition results from a velocity of $974 \mathrm{ft} / \mathrm{sec}$ at an altitude of $8554 \mathrm{ft}$ MSL (M0.9). The minimum dynamic pressure was calculated to be $190 \mathrm{lbs} / \mathrm{ft}^{3}$ which resulted from a velocity of $475 \mathrm{ft} / \mathrm{sec}$ at an altitude of $9405 \mathrm{ft} \mathrm{MSL} \mathrm{(M0.425).} \mathrm{In} \mathrm{most} \mathrm{cases}$ the orientation of the vehicle was predicted to be suitable for parachute deployment, however, in the scenario of a catastrophic structural failure the orientation was unpredictable due to the possibility of tumbling. Reliability of the parachute system was not guaranteed for the later situations.

The physical constraints for the packed parachute system were a diameter of 8.75 inches and a maximum length of about 45 inches. The parachute was supported by a tube which was constrained to a length of 28.5 inches. The remainder of the pack was allowed to extend unsupported into the tailcan. The maximum weight of the parachute system was unspecified but desired to be minimized. Based on the volume available and a maximum pack density of $35 \mathrm{lbs} / \mathrm{ft}^{3}$ a maximum weight of $55 \mathrm{lbs}$ was used for initial vehicle mass property calculations.

\section{Parachute System Design}

\section{Design Methodology}

The parachute system was designed using a new spreadsheet aided engineering tool developed in parallel with this program [ref. 1]. This spreadsheet tool combines the basic equations used in the beginning parachute design process to aid in the determination of the parachute diameter, the inflation forces, the need for reefing and the reefed diameter. The tool then aids in the formulation of the time versus drag area curve needed for the force-time-trajectory code. The spreadsheet tool allows the parachute canopy to be interactively designed, calculates the geometric porosity of the parachute, aids in evaluating the strength of materials required and selection of those materials for the parachute components, and estimates the initial parachute weight. Finally, the geometric specifications and patterns for the parachute components are calculated for fabrication.

The LAPTAP force-time-trajectory code was used to simulate the trajectory and determine the inflation forces and the CALA code [ref. 2] was used to predict the structural loads in the parachute structural components.

\section{0-lb Payload Parachute System}

The original parachute system design was performed for the $1350 \mathrm{lb}$. payload and with the philosophy that the deployment and inflation time for the parachute were not the primary considerations. This led to a design that minimized the deceleration loads on the airframe and maximized the drag area of the main parachute. In order to accomplish this design philosophy a 12.5 $\mathrm{ft}$-diameter drogue parachute was designed that provided a $10 \mathrm{~g}$ maximum deceleration and retarded the vehicle to a velocity that allowed deployment of a large 42-ft-diameter main parachute.

The drogue parachute was reefed to $21 \%$ based on drag area and utilized a 3 second delay reefing line cutter. The drogue parachute was a $20^{\circ}$ conical ringslot parachute with three 5.5-inch-wide rings constructed of $4.75 \mathrm{oz} / \mathrm{yd}^{2}$ nylon, two 8 inch wide rings constructed of $3.5 \mathrm{oz} / \mathrm{yd}^{2}$ nylon, and three 8 inch wide rings constructed of $2.25 \mathrm{oz} / \mathrm{yd}^{2}$ nylon. The suspension lines and radials were constructed of 1 " wide by $2400 \mathrm{lb}$. breaking strength Kevlar webbing. The suspension lines were 13 feet in length. Three $1 / 2$-inch by $550 \mathrm{lb}$. Kevlar miniradials were used on each gore with the center miniradial extending from skirt to vent and the outer mini-radials covering four slots.

A 4.0 second delay staging cutter was utilized for deployment of the unreefed 42-ft-diameter ringslot/solid main parachute. The main parachute was constructed from a modified F111 prototype parachute design [ref. 3]. The main parachute was fabricated by reducing the diameter of the F111 parachute from 49 feet to 42 feet. A new $1 / 2$-inch by $800 \mathrm{lb}$. Kevlar skirt reinforcement and 42 foot long suspension lines from the same material were then attached to the modified canopy. Two F111 
parachutes were modified to the 42 -ft-diameter and one was packed into a new deployment bag.

The drag area and time history was calculated for the parachute system and input into the LAPTAP time-force-trajectory code to evaluate the performance and ensure that the maximum vehicle deceleration loads were not exceeded. The structural integrity of the parachutes was modeled using the CALA code. A safety margin of 2.5 was calculated for all of the structural components.

A test program at the Naval Air Warfare Center at China Lake was being negotiated for parachute design validation. The program was to consist of two full-scale drop tests from a C-130 aircraft. The test vehicle was to free fall to an altitude of $2000 \mathrm{ft}$ AGL whereupon parachute deployment was to occur. The required minimum and maximum test velocities were $440 \mathrm{fps}$ and $730 \mathrm{fps}$.

\section{0-lb Payload Parachute System Design}

In January of 1996 the project was redirected with the major consequence for the parachute design being an increase in vehicle weight to $1900 \mathrm{lbs}$. Several options were considered for the heavier vehicle. The first option was to redesign the original system by strengthening the structure of the drogue parachute to withstand the higher loads and increasing the staging delay time before deployment of the modified F111 parachute. A second option considered was to redesign the drogue parachute as above but to further decrease the diameter of the F111 main parachute canopy. The final option was to throw out the old system design and completely redesign the system to a single stage system consisting of a small pilot parachute deploying a reefed main parachute. Based on flight termination system discussions in late 1995 which focused on turning all the fins in one direction as a backup for flight termination it appeared that decreasing the time for parachute deployment and inflation was a critical requirement in the design. Based on this requirement a new redesigned parachute system was chosen. This new design would minimize the time for parachute deployment and inflation but sacrifice main parachute drag area and therefore increase the impact velocity. We also asked for the maximum deceleration level to be increased to $15 \mathrm{~g}$ 's because the volume for the parachute was not increased, the new main parachute would need to be severely reefed for a $10 \mathrm{~g}$ maximum, the reefing line cutter delay time would need to be long to ensure that the disreefed load was less than the $10 \mathrm{~g}$ maximum, and the $15 \mathrm{~g}$ deceleration would help to decrease the range of the payload.

\section{Main Parachute Design}

\section{Design 1}

The main parachute was designed with the requirement to achieve maximum drag with minimal weight. Due to the high initial loads a $30-\mathrm{ft}-$ diameter hybrid ringslot/solid parachute with 32 gores was chosen for this application. This design incorporated the ringslot pattern in the vent region to withstand the initial loads and the solid section to maximize the drag coefficient. This initial design had six 5.5 inch wide rings with 0.8 inch slots. The top three rings were constructed from $4.75 \mathrm{oz} / \mathrm{yd}^{2}$ nylon and the bottom three rings were fabricated from $3.5 \mathrm{oz} / \mathrm{yd}^{2}$ nylon. The large solid section was fabricated from $2.25 \mathrm{oz} / \mathrm{yd}^{2}$ nylon. Therefore the canopy was about $22 \%$ ringslot and $78 \%$ solid as measured along the radial. The 30 foot long suspension lines and the radials were constructed from 1-inch-wide, $2400 \mathrm{lb}$. Kevlar webbing. The reefing line was 11 feet, 5 inches in length and fabricated from $1 / 2$-inch by $3500 \mathrm{lb}$. Kevlar webbing. The reefing ratio of reefed drag area to full open drag area was calculated to be $6.4 \%$. Reefing rings were attached to the skirt at each suspension line/skirt intersection. Two $2.5 \mathrm{sec}$ delay reefing line cutters were attached in two locations.

Two parachutes of this design were fabricated and packed in the parachute lab. The packed weight of the main parachute was $32 \mathrm{lbs}$. The total system weighed $35.5 \mathrm{lbs}$. The design process utilized the new spreadsheet parachute design tool. CALA results showed that the maximum load in the rings, solid section, radials, and suspension lines were less than $40 \%$ of rated strength. This parachute was tested at the maximum dynamic pressure and sustained severe structural damage. The test details are included in the test program section. The damage was attributed to a skirt first inflation of the canopy which resulted in higher than expected loads in the solid section of the canopy.

\section{Design 2}

Following the structural failure of the solid section modifications were made to the canopy to control the inflation process and prevent the solid section from loading before the ringslot section.

The first major modification was to add midgore reefing designed to control the solid section 
material near the skirt so that it could not capture a large influx of air during the initial inflation process.

The second major modification was to change the ringslot/solid ratio of the canopy such that the ringslot section was about $63 \%$ of the canopy and the solid section was about $37 \%$ of the canopy as measured on the canopy radial. This modification reduced the solid section percentage of the total drag surface area from about $92 \%$ in design 1 to about $38 \%$. This modification was designed to reduce the possibility of a large influx of air overloading the solid panels. The tradeoff was a decrease in the drag coefficient for the parachute canopy.

Third, the materials used to fabricate the canopy were modified to strengthen the structure of the canopy. The new design had eighteen 5.5 inch wide rings and a 68.57 inch solid section. The top six rings were fabricated from $7 \mathrm{oz} / \mathrm{yd}^{2}$ nylon, the middle 5 were fabricated from $4.75 \mathrm{oz} / \mathrm{yd}^{2}$ nylon, and the bottom seven were fabricated from 3.5 $\mathrm{oz} / \mathrm{yd}^{2}$ nylon. The solid section was fabricated from $3.5 \mathrm{oz} / \mathrm{yd}^{2}$ nylon. These material changes increased the weight of the main parachute to $48 \mathrm{lbs}$, an increase of $150 \%$ over design 1.

Additional minor modifications were made by reducing the vent diameter from $10 \%$ of the constructed diameter to $5 \%$ and by adding $5 \%$ fullness to the top of the solid pattern gore which then decreased to $1 \%$ fullness at the skirt. Because the materials used in the new design weighed more the deployment bag length was increased 7 inches to 34 inches. Finally, the reefing line cutter delay time was increased to 3 seconds. Two systems were fabricated and packed in the Sandia parachute laboratory.

\section{Pilot Parachute Design}

The pilot parachute designed to extract the main parachute was a 3.5-ft-diameter, six gore Guide Surface parachute constructed of $4.75 \mathrm{oz} / \mathrm{yd}^{2}$ nylon. The suspension lines and the radials were fabricated from 1-inch-wide, 2400-lb Kevlar web. The suspension lines were 12 feet in length to ensure that the pilot parachute was sufficiently behind the wake region of the payload during main parachute extraction. This parachute successfully deployed the main parachute on all four sled tests. The drag area of the pilot parachute was calculated to be about 7.8 $\mathrm{ft}^{2}$ resulting in a maximum bag strip velocity at the maximum dynamic pressure of about $490 \mathrm{ft} / \mathrm{sec}$. The pilot parachute was packed into an envelope style deployment bag which was deployed by the explosively ejected tailcan.

\section{Reefing Line System}

A $3500 \mathrm{lb}$. Kevlar web reefing line was installed through reefing rings attached to the radials on the first design and at additional rings placed at the mid-gores on the second design. As previously noted a 2.5 second delay cutter was used on the first test. This was changed to a three second delay Technical Ordnance reefing line cutter $(\mathrm{P} / \mathrm{N}$ TKO215803) for the final design.

The length of the reefing line was 11 feet, 5 inches on the first and second test. The data from the second test indicated that the maximum deceleration was above $15 \mathrm{~g}$ 's. The length of the reefing line was reduced to 10 feet, 2 inches for the final test and found to be satisfactory.

\section{Deployment System Design}

Parachute deployment was accomplished by explosive release and expulsion of the tailcan. The explosive utilized was a 35 grain/foot aluminum linear shape charge which severed the tailcan and accelerated it to a velocity of between $40-50 \mathrm{ft} / \mathrm{sec}$. The function of the tailcan deployment system was successfully demonstrated in a test performed at the Explosive Component Facility prior to the first sled test. The tailcan deployed the packed pilot parachute which in turn deployed the main parachute. The design used on these development test will be used, after being modified to fit the geometry, on the prototype flight test vehicle.

\section{Test Program}

The Sandia National Laboratories sled track was utilizing for testing of the flight termination parachute system. The test program was designed to test the parachute at maximum, minimum, and $120 \%$ maximum design dynamic pressure. The first test was performed at the maximum dynamic pressure and resulted in failure of the initial design. After the parachute was redesigned a second test was successfully performed at maximum dynamic pressure. The third test was performed at the minimum dynamic pressure condition with the purpose of demonstrating proper deployment and inflation at minimum loading. The final test was performed at $120 \%$ maximum dynamic pressure and demonstrated a level of structural margin in the parachute design. 


\section{Sled Track Test Setup}

The tests of the flight termination parachute system were performed at the Sandia rocket sled facility. This facility consists of a 10,000 foot narrow gauge track, instrumentation capabilities, and unique testing techniques. The test vehicle was mounted on a sled and accelerated down the track using NIKE rocket motors. The vehicle was then pneumatically ejected from the sled to achieve altitudes between 250 and 300 feet for parachute deployment. Simulations of the rocket motor performance were combined with test vehicle aerodynamic performance to determine correct timing for test vehicle ejection from the sled and timing for parachute deployment. Trajectory simulations of parachute performance were used to determine initial starting position of the sled for a desirable impact position.

The parachute vehicle was tracked using the Sandia laser tracker. The tracker provides spacetime-position data and is also equipped with high speed movie cameras and video cameras for optically recording the flight of the test vehicle. In addition, high speed cameras were used to measure velocity at vehicle ejection from the sled and to document the test results.

On the tests that incorporated accelerometers the data was telemetered to a trackside ground station and recorded for analysis.

\section{Test Vehicle Design}

The test vehicle utilized for the sled tests was reconfigured from an existing vehicle built from an expended Nike rocket motor and is shown in figure 1. Hardware for the incorporation of the parachute in the vehicle were designed by the project engineers and fabricated in the Sandia machine shop. Personnel from the sled track facility made modifications to the test vehicle to increase the weight and to position the center of gravity in the correct, location for stable ejection from the sled.

A fireset was designed for the test vehicle to initiate the deployment system detonators at the correct time following ejection from the sled. The detonator firing circuit was fabricated using a similar circuit as that to be used for the actual prototype flight test termination system. For the final three sled tests an instrumentation package with a tri-axial accelerometer block and telemetry system were added. In addition, onboard cameras were added to the test vehicle before the second test. . These cameras allowed for analysis of the deployment system and parachute performance during deployment.

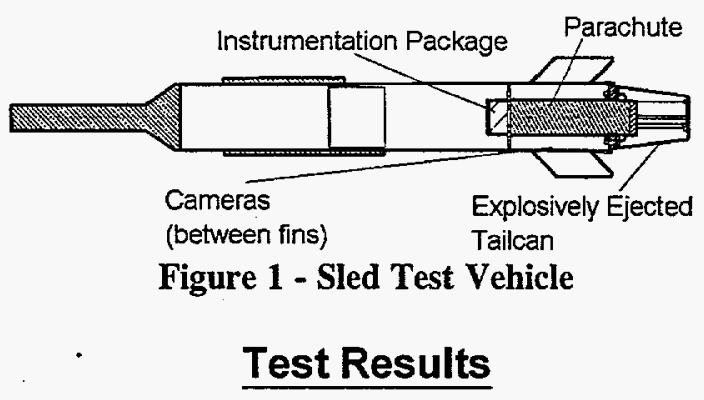

\section{Summary}

Two design 1 parachutes were fabricated and packed in the parachute laboratory before the first sled test. The plan was to use one parachute for the maximum dynamic pressure test and then to reuse the same system for the minimum dynamic pressure test. The second parachute was scheduled for the overtest. Four tailcan assemblies were fabricated and the explosive linear shaped charge was installed. The rocket performance and trajectory simulations were performed and the correct starting position was determined such that impact occurred in an acceptable location.

\section{Sled Test 1}

Sled test $\# 1$ was performed on May 16, 1996. The test was designed to show performance of the parachute at the maximum expected velocity and dynamic pressure condition.

The deployment system performed as expected and properly deployed the pilot parachute followed by the main parachute. The main parachute was extensively damaged during the inflation phase. It appears that the initial ball of air overexpanded the solid panels of the parachute starting at the skirt and caused structural failure of the material before it reached the ringslot section and the vent region. In some cases the solid portion of the gore was completely separated from the canopy. The results of this test showed that design 1 was not an acceptable design and led to extensive modifications to the canopy as listed in the parachute design section.

Position and velocity data for this test are not available due to failure of the laser tracker to maintain track on the vehicle. However, a high 
speed camera was used to verify that the velocity at ejection was close to that predicted in the simulation. From this one data point and from the results of tests 2 through 4 we can assume that the deployment conditions were approximately correct. The impact position of the vehicle was much farther than predicted but can easily be explained by the damage to the canopy which reduced the parachute drag.

The fact that there was no data collected from this test illustrated the importance of data for successful evaluation of parachute performance. This led to the addition of a second backup laser tracker, onboard cameras, and an accelerometer package for sled test 2.

\section{Sled Test 2}

Sled test \#2 was performed on June 27, 1996. The test was a repeat of test $\# 1$ and was designed to show performance of the redesigned parachute at the maximum deployment conditions. Data was obtained from both laser trackers. The actual weight of the test vehicle was $2021 \mathrm{lbs}$ with a parachute weight of $51.8 \mathrm{lbs}$. Figures 2 and 3 show the velocity and acceleration, respectively, of the vehicle from rocket ignition through ejection, free flight, parachute deployment and inflation, and finally impact. Figure 4 shows the calculated drag area (acceleration $\mathrm{x}$ vehicle weight/dynamic pressure) of the parachute system.

The data shows that the parachute was deployed at about $975 \mathrm{ft} / \mathrm{sec}$ corresponding to a dynamic pressure of about $959 \mathrm{lbs} / \mathrm{ft}^{3}$, which is about $10 \%$ higher than requested. The drag area of the reefed parachute was about $50 \mathrm{ft}^{2}$ which resulted in a deceleration of $19 \mathrm{~g}$ 's. The drag area of the full

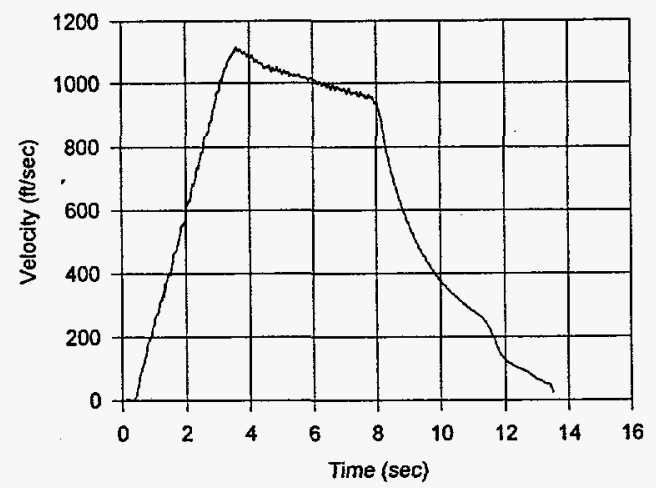

Figure 2 - Velocity vs. Time

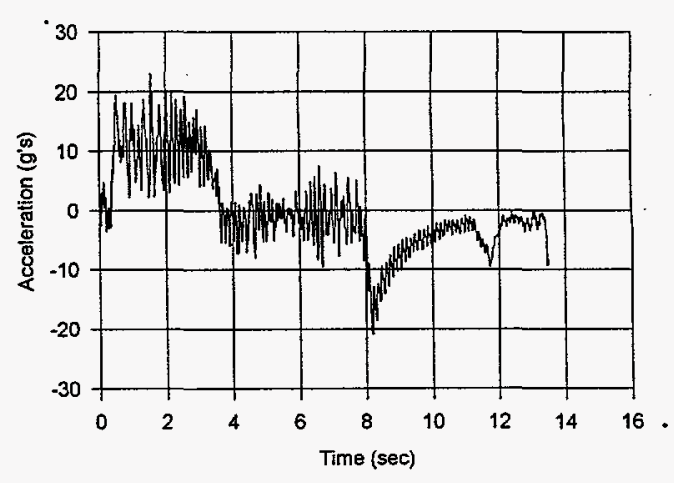

Figure 3 - Acceleration vs. Time

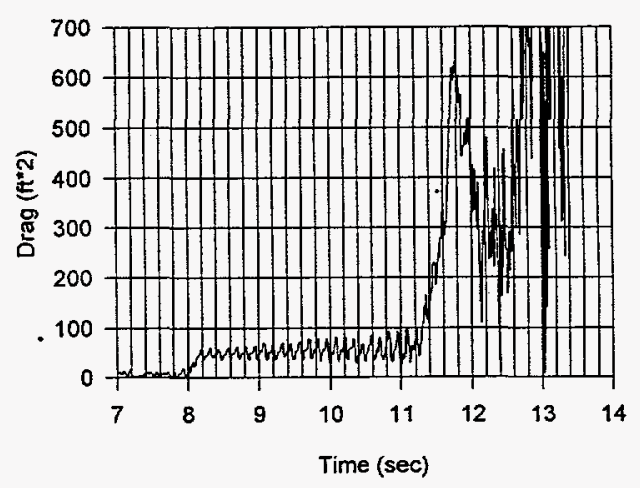

Figure 4 - Drag Area vs. Time

open parachute is difficult to determine from the data but appears to be in the $600 \mathrm{ft}^{2}$ range at first inflation. Wake recontact then decreased the drag to about $250-300 \mathrm{ft}^{2}$ before canopy recovery to about $500 \mathrm{ft}^{2}$. Due to the short flight time the steady state drag area of the parachute cannot be determined from the test. The full open parachute deceleration was about $9.5 \mathrm{~g}$ 's. This data indicates that the reefed drag area needed to be decreased to keep the deceleration below the $15 \mathrm{~g}$ maximum requirement. This decrease will, in turn cause a slight increase in the full open deceleration. It was determined that the reefing line cutter delay should remain the same.

The only damage to the parachute was isolated to the top central area of several solid panels. This damage did not appear to substantially affect the performance of the parachute. The onboard cameras showed that the damage occurred during the inflation of the canopy but was inconclusive as to whether it happened during the maximum load condition (when the parachute is about $67 \%$ full open or due to overinflation. Two possible reasons 
were theorized for this damage. The first theory was that the mini-radial that attached to the solid portion was creating large forces in the material. The second was that the parachute was overinflating and creating large forces in the solid section. In an attempt to eliminate this damage the mini-radial was terminated below the bottom ring and an overinflation line was added to the parachute canopy at the skirt.

The accelerometers which were installed on this vehicle failed. Because the accelerometer block was hard mounted to the base plate, speculation was that the shock from the explosive initiation of the tailcan damaged the accelerometers. Consultation with accelerometer experts confirmed this diagnoses. A mounting design with accelerometers attached to the block with isolator pads was implemented for the next test.

\section{Sled Test 3}

Sled test \#3 was performed on August 13, 1996. The purpose of this test was to demonstrate proper deployment of the parachute at the minimum corner of the deployment envelope. The parachute was deployed properly during the test and, although the inflation of the main parachute was slower than on the high speed test, the performance was as modeled. Figures 5 and 6 show the velocity and acceleration history of the test. Deployment of the parachute was initiated at the velocity of about 420 $\mathrm{ft} / \mathrm{sec}$ which corresponds to a dynamic pressure of about $180 \mathrm{lbs} / \mathrm{ft}^{3}$. This deployment condition was a little lower than requested but helped to demonstrate some margin in the deployment system. As expected the deceleration loads during parachute inflation were very low. The drag area is illustrated in figure 7 . Note that the reefing line length was not

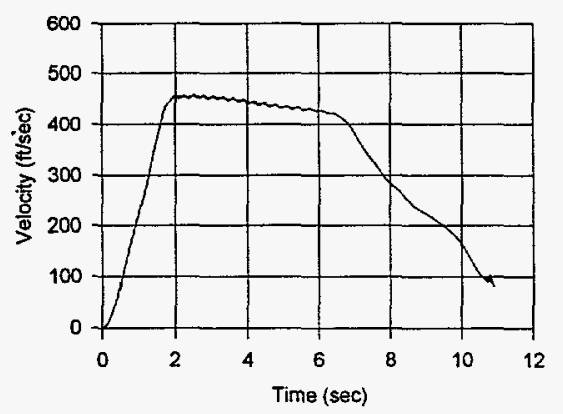

Figure5 - Velocity vs. Time

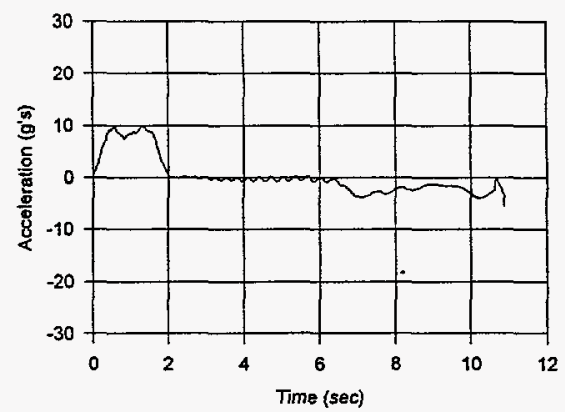

Figure 6 - Acceleration vs. Time

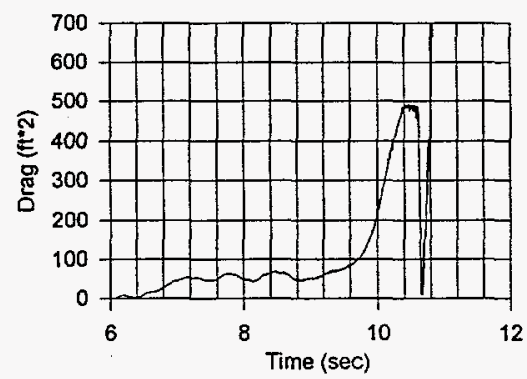

Figure 7 - Drag Area vs. Time

modified for this test so the reefed drag area is about $50 \mathrm{ft}^{2}$. Full open drag was about $490 \mathrm{ft}^{2}$.

\section{Sled Test 4}

Sled test \#4 was performed on August 20, 1996. The test was designed to test the parachute at $120 \%$ maximum dynamic pressure with the purpose of evaluating the performance margin of the parachute. This parachute incorporated the modifications as determined from the results of test 2. Figures 8 and 9 show the velocity and acceleration profiles of the test as determined from the laser tracker data. The deployment velocity was about $1070 \mathrm{ft} / \mathrm{sec}$ which results in a dynamic pressure of about $1155 \mathrm{lb} / \mathrm{ft}^{2}$. This compares to the desired parachute deployment condition of $1045 \mathrm{ft} / \mathrm{sec}$ and $1050 \mathrm{lbs} / \mathrm{ft}^{2}$. The actual dynamic pressure deployment condition is about $130 \%$ of the expected flight test maximum. As shown in figure 9 the integrated laser tracker data shows that the reefed deceleration was about $18 \mathrm{~g}$ 's and the full open deceleration was about $10 \mathrm{~g}$ 's. The deceleration levels from the an-board 
accelerometer were $22.2 \mathrm{~g}$ 's reefed and $11.8 \mathrm{~g}$ 's full open. These number compare favorably with the predicted levels of $19.5 \mathrm{~g}$ 's and $12.9 \mathrm{~g}$ 's respectively and confirm that the shorter reefing line length will result in deceleration levels under $15 \mathrm{~g}$ 's for the maximum deployment condition.

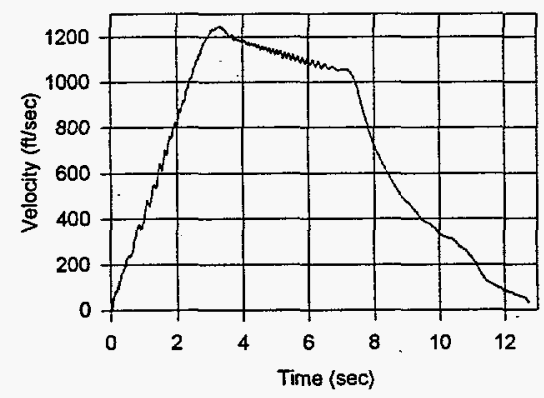

Figure 8 - Velocity vs. Time

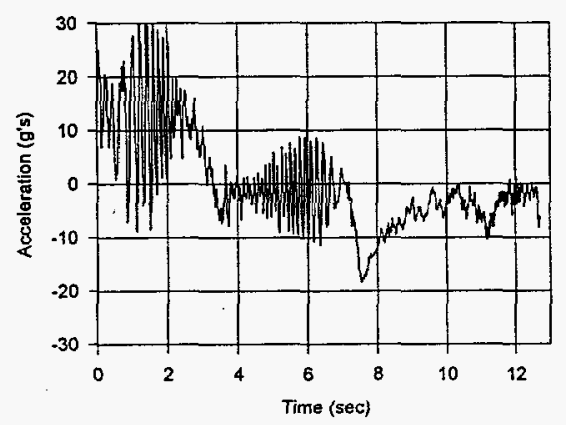

Figure 9 - Acceleration ys. Time

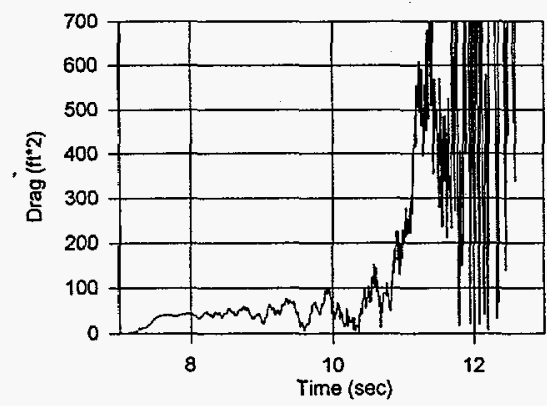

Figure 10 - Drag Area vs. Time
The shorter reefing line length resulted in an initial reefing line drag area of about $35 \mathrm{ft}^{2}$. The full open drag area with the overinflation line peaks at a value slightly larger than $500 \mathrm{ft}^{2}$.

Damage was still noted in the top central portion of the solid sections. This damage does not significantly affect the performance of the parachute but the cause of the damage is perplexing. The hypothesis is that during the initial inflation phase the ball of air creates a bulge in the solid section which is halted when the reinforcement at the top of the section is reached. The resulting high pressure region causes structural failure of the material before the air can escape around the reinforcement. I have recommended that some type of slots be incorporated into the top central portion of the solid section to allow this high pressure air to escape without damaging the fabric. Several possible solutions could be tested during one additional test. However, it appears that another test will not be possible.

\section{Conclusion and Recommendations}

A parachute has been successfully designed for the flight termination system for a $1900-\mathrm{lb}$. gliding delivery platform. Four full-scale sled tests of the system have been performed and data obtained to validate the performance of the system.

Modifications to the reefing line system were made based on the data obtained to ensure that maximum deceleration loads were not exceeded. The data indicates that, with these modifications, the parachute will meet the requirements. Although some damage to the solid sections of the canopy were observed on the sled tests, the damage was minor and did not significantly detract from the performance of the parachute system.

I have designed and incorporated minor modifications to the solid section of the flight test parachute in an attempt to alleviate the damage noted on tests 2 and 4 . The modifications incorporated are slots in the top central portion of the solid sections to allow escape of the air before damage to the fabric occurs. Three slot patterns, one with the slots oriented vertically, one with the slots oriented horizontally, and the last with a triangular shape, were devised with the same open area. Each pattern was incorporated into eight gores and the final eight gores were unmodified. Each of the four gore designs, three with slots and one 
unmodified, was alternated throughout the canopy during construction. If another sled test can be incorporated into the program these modifications can be evaluated. If no further testing is performed the efficacy of these changes will only be evaluated if the parachute is used to terminate the prototype flight test.

\section{$\underline{\text { References }}$}

[1]Waye, D. E., "Development of a SpreadsheetAided Engineering Tool for the Design of Parachute Systems", to be presented, AIAA 14th Aerodynamic Decelerator Conference, San Francisco, CA., Paper No. AIAA97-1450, June 1997.

[2]Sundberg, D. W., "A New Solution Method for Steady-State Canopy Structural Loads", Journal of Aircraft, Vol. 25, November 1988, pp. 1045-1051.

[3]Johnson, D. W., "Testing of a New Recovery Parachute System for the F111 Aircraft Crew Escape Module -- An Update", AIAA 10th Aerodynamic Decelerator Conference, Cocoa

Beach, FL., Paper No. AIAA89-0891, April 1989. 